Bull. Fac .Agric., Cairo Univ., 68:207-221 (2017).

\title{
MAGNETIZED WATER EFFECT ON SOME SOIL PROPERTIES AND GROWTH OF MAIZE PLANT (ZEA MAIZE)
}

(Received: 12 .4.2017)

\author{
By \\ E.S. Abd-El hady and O.M. Rady \\ Soils and Water Department, Faculty of Agriculture, Al- Azhar University, Cairo, Egypt
}

\begin{abstract}
The main purpose of the present study was to investigate the influence of magnetic water treatment on some soil properties and some growth parameters of maize plant. The replicated pot experiments involved magnetically treated water (passed through a magnetic field $10000 \mathrm{G}$ ) and nonmagnetically treated water using three types of soils clay, sandy and calcareous. The results of this study indicated that the magnetized water had a positive effect on water properties where it reduced the surface tension, and viscosity of water, while the dissolved oxygen increased. The results indicated that magnetic treatments of water had no significant effect on the electrical conductivity, $\mathrm{pH}$ and soluble ions in the soil after harvest. The hydraulic conductivity increased by using magnetized water in all tested soils. The percentages of increase in hydraulic conductivity with magnetized water were 31.8, 3.14 and $7.52 \%$ over non -magnetized water for the clay, sandy and calcareous soils, respectively. Using magnetized water and organic matter were the most effective treatment in seed germination. The percentages increase of maize germination after 6 days were 10.10, 5.89 and $21 \%$ for magnetized water compared with non-magnetized water in the clay, sandy and calcareous soils, respectively.The magnetized water increased the availability of some nutrients in the soil (N, P and K) which lead to increase the concentration in the plant. The highest mean values were 147.57, 34.59 and $118.51 \mathrm{mg} \mathrm{pot}^{-1}$ for $\mathrm{N}, \mathrm{P}$ and $\mathrm{K}$, respectively, in the clay soil with magnetized water, while the lowest mean values were $78.27,17.67$ and $97.28 \mathrm{mg} \mathrm{pot}^{-1}$ in the sandy soil with non-magnetized water. In general, the study indicated some useful and applied effects of magnetized water on some soil properties and plant growth and thus increase production.
\end{abstract}

Key words:magnetized water, soil properties.

\section{INTRODUCTION}

Natural water is a multiphase system that contains micro and macro particles of organic and inorganic nature, including different ions. Among different physical and chemical methods of natural water treatments, magnetic methods attract a special attention due to their ecological purity, safety, and simplicity.

When water is exposed to a magnetic field, the 'so-called' magnetization of water changes its properties, for example, changes in the viscosity, surface tension force, freezing and boiling points, and electric conductivity compared with pure water (Amiri and Dadkhah, 2006; Pang and Deng, 2008a). The magnetized water has a high dissolving capacity for desalinization from the soil; it removed 50 to $80 \%$ of soil $\mathrm{Cl}^{-}$, as compared to a removal of only $30 \%$ by non-magnetized irrigation water.
Moreover, magnetized water removed $30 \%$ of $\mathrm{HCO}_{3}^{-}$while normal water removed nothing. Magnetized water also doubled the leaching of $\mathrm{SO}_{4}^{-2}$ and increased $\mathrm{O}_{2}$ content by $10 \%$ (Takatshinko,1997).

The soil physical and chemical properties change in magnetically treated water lead to the understanding of the reclamation effect (1) increased the permeability of soil, which gives an appreciable increase of irrigation efficiency, (2) Increased in the amount of $\mathrm{CO}_{2}$ and $\mathrm{H}^{+}$in alkaline soils which is similar to the addition of fertilizers which converts insoluble carbonates into soluble bicarbonates (Bogatin et al., 1999).

The application of magnetic water at $60 \%$ or $55 \%$ of the field capacity decreased soil salinity and increased available nutrients $(\mathrm{N}, \mathrm{P}$, and $\mathrm{K}$ ). The combinations between the application of magnetic water and water regimes 
at $60 \%$ or $55 \%$ enhanced water use efficiency (Ahmed and Abd El-kader, 2016). The mean soil moisture content at different soil depths below the dripper pipes for the magnetized irrigation water treatment were more than the nonmagnetized irrigation water treatment and the differences were significant at the 5\% level. The irrigation with magnetic water as compared with the nonmagnetic water increased soil moisture up to $7.5 \%$, and this increase was significant at the 1\% level (Mostafazadeh-Fard et al., 2011; Khoshravesh et al., 2011).

Colloidal stability is influenced by magnetic fields through an alteration of the structure of water molecules and ions either adsorbed on the particle surface or in the medium. The changes caused by the magnetic influence depend on many factors, such as strength of the magnetic field, direction of applied magnetized field, duration of magnetic exposure, flow rate of the solution (Higashitani and Oshitani, 1997). In the calcareous soil, magnetized irrigation water had a positive effect in delaying the surface crust formation and consequently increasing the success of seedling to emerge above as compared with normal water, it has more than tripled soil moisture retention, and also, weakens the soil compaction and hardness (Hilal and Hillal, 2000a).

The use of magnetized saline water had the valuable effect on soil and plant, where the electrical conductivity of the soil decreased and the plant growth parameters improved. Additionally it improved fresh and dry weights of tomato plants compared to the control (Mohamed, 2013). Irrigation with magnetized water significantly increased the physiologic factors such as germination percentage, roots and shoots length, fresh and dry weight of shoots and roots, chlorophyll content index, water uptake, tissue water content (Aghamir et al., 2016).

The aim of the current study is to evaluate the applicability of using the magnetized water and its effect on soil and plant properties.

\section{MATERIALS AND METHODS}

Pot experiments were carried out at the farm of the Soils and Water Department, Faculty of Agriculture, Al-Azher University, Nasr City, Cairo, Egypt, to study the effect of magnetized water on some soil properties (chemical and physical) and some growth parameters of maize.
Three surface soil samples $(0-20 \mathrm{~cm}$ depth) were collected, the first from Mashtol El Souq, Sharkia Governorate to represent the clay soils, the second from Wade El Natroon, El Behaira Governorate to represent the sandy soils and the third one from El Nobaria, El Behaira Governorate to represent the calcareous soils. Soil samples were air- dried, crushed and sieved to pass through a $2 \mathrm{~mm}$ sieve and analyzed for some chemical and physical characteristics, the results are presented in Table 1( $a$ and $b$ ).

The soil samples were packed in 36 plastic pots, $25 \mathrm{~cm}$ in diameter and $20 \mathrm{~cm}$ depth, with 4 $\mathrm{kg}$ soil per pot, and these pots were arranged into two groups: In the first group the soils in the pots were mixed with organic matter by $75 \mathrm{~g}$ per pot (sheep manure) and in the other group no organic matter was added. The pots were irrigated with either magnetized or nonmagnetized water. Four treatments were applied in a randomized complete blocks design with three replicates for the investigated soils.

The magnetic treatment of water was done by passing the water through the magnetic treatment device to gain a magnetic moment; its diameter is 0.5 inch with magnetic flux intensity of 10000 gausses. Some chemical properties of water before and after magnetization as shown in Table (2).

Prior planting, the soil was fertilized by both phosphorus and potassium at rates of 0.8 and $0.2 \mathrm{~g} / \mathrm{pot}$ as calcium tri phosphate and potassium sulphate, respectively. After two weeks, the nitrogen fertilizer was added at recommended rate represent the recommended rates, of $1.6 \mathrm{~g} / \mathrm{pot}$ as ammonium nitrate. maize seeds were cultivated (10 kernel grain per pot). Soil moisture content, during the plant growth period, was kept at about the field capacity. After complete germination, maize seedlings were thinned into 4 plants per pot.

After 48 days from sowing, plants were cut at $1 \mathrm{~cm}$ above the soil surface to measure the plant growth parameter (plant length, fresh weight of shoots and roots) then oven dried at $70^{\circ} \mathrm{C}$, the dried plant samples were grounded and acid digested to estimate their contents of $\mathrm{N}, \mathrm{P}$ and K. After harvest, soil samples were collected from each pot, air-dried, crushed and passed through a $2 \mathrm{~mm}$ sieve and kept for analyses.

\subsection{Soil physical analyses}


Table (1): Some physical and chemical properties of the soils under study before planting a) Physical properties

\begin{tabular}{|c|c|c|c|c|c|c|}
\hline \multirow{2}{*}{$\begin{array}{c}\text { Soil sample } \\
\text { location }\end{array}$} & \multicolumn{3}{|c|}{$\begin{array}{c}\text { Partical size } \\
\text { distribution \% }\end{array}$} & \multirow{2}{*}{ Texture } & $\begin{array}{c}\text { Real density } \\
\mathbf{M g ~ m}^{-3}\end{array}$ & $\begin{array}{c}\text { Bulk } \\
\text { density } \\
\mathbf{M g ~ m}^{-3}\end{array}$ \\
\cline { 2 - 4 } & Sand & Silt & Clay & & 1.93 & 0.90 \\
\hline Mashtol El-Souq & 34.47 & 28.98 & 36.55 & Clay loam & 2.80 & 1.46 \\
\hline Wade El-Natroon & 94.66 & 1.02 & 4.32 & Sandy & 2.50 & 1.30 \\
\hline El-Nobaria & 57.00 & 20.59 & 22.41 & Sandy clay loam & \\
\hline
\end{tabular}

b) Chemical properties

\begin{tabular}{|c|c|c|c|c|c|c|c|c|c|c|c|c|}
\hline \multirow{3}{*}{$\begin{array}{l}\text { Soil sample } \\
\text { location }\end{array}$} & \multirow{3}{*}{$\begin{array}{c}\text { pH } \\
\text { 1:2.5 } \\
\text { Soil } \\
\text { suspension }\end{array}$} & \multirow{3}{*}{$\begin{array}{c}\mathrm{EC} \\
\mathrm{dSm}^{-1} 1: 5 \\
\text { soil water } \\
\text { extract }\end{array}$} & \multicolumn{8}{|c|}{$1: 5$ soil water extract } & \multirow{3}{*}{$\underset{\mathrm{g} \mathrm{kg}^{-1}}{\mathrm{CaCO}_{3}}$} & \multirow{3}{*}{$\begin{array}{l}\text { O.M } \\
\mathrm{g} \mathrm{kg}^{-1}\end{array}$} \\
\hline & & & \multicolumn{4}{|c|}{$\begin{array}{c}\text { Soluble Cations } \\
\text { cmol }_{\mathrm{c}} \mathbf{~ k g}^{-1}\end{array}$} & \multicolumn{4}{|c|}{$\begin{array}{l}\text { Soluble Anion } \\
\mathrm{cmol}_{\mathrm{c}} \mathbf{~ k g}^{-1}\end{array}$} & & \\
\hline & & & $\mathrm{Ca}^{2+}$ & $\mathrm{Mg}^{2+}$ & $\mathbf{N a}^{+}$ & $\mathbf{K}^{+}$ & $\mathrm{CO}_{3}{ }^{2-}$ & $\mathrm{HCO}_{3}^{-}$ & $\mathrm{Cl}^{-}$ & $\mathrm{SO}_{4}{ }^{2-}$ & & \\
\hline Mashtol El-Souq & 7.80 & 1.88 & 2.85 & 2.31 & 3.68 & 0.03 & - & 1.19 & 2.38 & 5.3 & 32.20 & 10.20 \\
\hline Wade El-Natroon & 7.78 & 2.15 & 4.45 & 3.98 & 2.25 & 0.04 & - & 2.25 & 2.24 & 6.34 & 87.70 & 3.40 \\
\hline El-Nobaria & 8.01 & 2.92 & 6.95 & 5.25 & 2.51 & 0.15 & - & 3.87 & 2.35 & 8.64 & 185.2 & 7.70 \\
\hline
\end{tabular}

Table (2): Some chemical properties of the magnetized (M.W) and non-magnetized waters (N.W)

\begin{tabular}{|c|c|c|c|c|c|c|c|c|c|c|c|c|c|}
\hline \multirow{2}{*}{$\begin{array}{c}\text { Water } \\
\text { treatment }\end{array}$} & \multirow[t]{2}{*}{ pH } & \multirow{2}{*}{$\begin{array}{l}\text { D.O } \\
\mathrm{mg} \mathrm{L}^{-1}\end{array}$} & \multirow{2}{*}{$\begin{array}{l}\text { surface } \\
\text { tension }\end{array}$} & \multirow{2}{*}{ 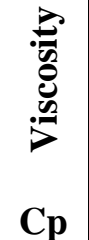 } & \multirow{2}{*}{$\begin{array}{c}\mathbf{E C} \\
\mathrm{dSm}^{-1}\end{array}$} & \multicolumn{4}{|c|}{$\begin{array}{l}\text { Soluble cations } \\
\text { mmol }_{\mathbf{c}} \mathbf{L}^{-1}\end{array}$} & \multicolumn{4}{|c|}{$\begin{array}{l}\text { Soluble anion } \\
\text { mmol }_{c} \mathbf{L}^{-1}\end{array}$} \\
\hline & & & & & & $\mathrm{Ca}^{2+}$ & $\mathbf{M g}^{2+}$ & $\mathrm{Na}^{+}$ & $\mathbf{K}^{+}$ & $\mathrm{CO}_{3}{ }^{2-}$ & $\mathrm{HCO}_{3}^{-}$ & $\mathrm{Cl}^{-}$ & $\mathrm{SO}_{4}^{2-}$ \\
\hline N. W & 7.63 & 3.23 & 71.27 & 1.05 & $\begin{array}{l}0.38 \\
\end{array}$ & 1.2 & \begin{tabular}{|l|}
0.84 \\
\end{tabular} & 1.2 & 0.48 & - & 1.21 & 1.18 & 1.33 \\
\hline M.W & 7.55 & 5.22 & 70.82 & 1.02 & 0.4 & 1.5 & 0.88 & 0.97 & 0.65 & - & 1.19 & 1.15 & 1.66 \\
\hline
\end{tabular}

dissolved oxygen

N.W: non-magnetized water

M.W magnetized water

Bulk density was measured by parafine method according to USADA (1996).

Real density: was measured by pycnometer method according to Estefen et al., (2013).

Particl size distribution was carried out by hydrometer method according to Sakar and Hadar (2005). Hydraulic conductivity was determined according to the Darcy's equation Klute (1986)

\subsection{Soil chemical analyses}

Soil reaction $(\mathrm{pH})$ was measured in 1:2.5 soil-water suspension using $\mathrm{pH}$ meter as reported by Page et al. (1982). Electrical Conductivity was measured with the EC meter in 1:5 soil water extracts according to Sarkar and Haldar, (2005). Soluble cations and anions were measured in 1:5 soil-water extract according to Pansu (2003). Organic matter content was determined by wet-oxidation, Walkely-Black method as described by Bashour et al. (2007). Total carbonate was estimated by using calcimeter method according to Leoppert and Suarez (1996). Available P was extracted by 0.5 $\mathrm{M} \mathrm{NaHCO}$ at $\mathrm{pH}$ 8.5. The extracted $\mathrm{P}$ was measured spectrophotometrically using stannous chloride phosphomolybdaic acid system as described by Cottiene et al. (1982). Available K was extracted by ammonium acetate method and measured by flame photometry Estefen et al. (2013). Available $\mathrm{N}$ was extracted by $\mathrm{K}_{2} \mathrm{SO}_{4}$ and determined by the distillation in a micro Kjeldahl according to Page et al. (1982). Viscosity and surface tension of soil extract were measured by Ostwald viscometer and capillary rise method, respectively, according to Levitts, (1972). Dissolved oxygen of water was determined using dissolved oxygen meter according to the Active Standard ASTM D888 (2012).

\subsection{Plant analyses}

The oven dried materials $0.2 \mathrm{~g}$ (shoot) were wet digested with concentrated sulfuric acid and $30 \%$ hydrogen peroxide. The digest solutions were analyzed for $\mathrm{N}$ in plant was determined by using the micro Kjeldahl method according to Cottiene et al. (1982). P was determined by spectrophotometer, Estefan et al. (2013). K was determined by the flam photometer method, 
(Cottiene et al., (1982).

All data were exposed to the proper statistical analysis according to Gomez and Gomez, (1984).

\section{RESULTS AND DISCUSSION}

When the water passes through the magnetic field, its structure and some physical characteristics will be changed. The magnetic field changes, the distribution of molecules and enhancement in the hydrogen bond strength, which leads to change some properties of water.

The data presented in Table (2) show the values of some water chemical and physicochemical analyses such as $\mathrm{pH}, \mathrm{EC}$, dissolved oxygen, soluble cations and anions, surface tension and viscosity. The use of magnetized water gave a slight increase in EC and dissolved oxygen. On the other hand, there was a slight decrease in $\mathrm{pH}$ value, viscosity and surface tension. These results are in agreement with those of Yang et al. (2011); Ali et al. (2014) and Hassan (2015) who reported that dissolved oxygen D.O is one of the main characteristics of water that indicates its quality, in addition to its importance as a limiting factor of irrigation water productivity, increasing D.O in irrigation water is leading to the increase of biological activities that enhances the water-soil-plant interaction.

The magnetic field weaken scohesive force between water molecules at water lair interface. The surface tension of water changes according to the change of the microscopic structure of water molecules when exposed to a magnetic field. The extenuation of contact angles of magnetized water is due to the increase of polarized effect and the changes of distribution and clustering structure of water molecules after magnetization Pang and Deng (2008b).

\subsection{Effect of magnetized water on hydraulic conductivity of the investigated soils}

Data in Table (3) and Fig.(1) revealed that the hydraulic conductivity increased by using magnetized water in all tested soils. The percentages of increase with magnetized water were $31.8,3.14$ and $7.52 \%$ for the clay, sandy and calcareous soils, respectively.

Also it is noticed from Table (3) that the hydraulic conductivity in the clay soil increased in the presence of the organic matter while in the sandy and the calcareous soils the hydraulic conductivity decreased in the presence of organic matter. In the heavy textured soil, magnetized water contributes to remove of the sodium salts and therefore improves permeability and increases the hydraulic conductivity. This result is in agreement with that of Bogatin et al. (1999) who reported that the magnetic field increases permeability of irrigation water in soil, which results in an appreciable increase of irrigation efficiency.

Contents of soluble ions in soils after harvest of the plant as influenced by magnetized irrigation water are presented in Tables (4). Comparing data in Tables (1-b) with (Table 4) which represent the chemical analyses of the investigated soils before and after cultivation, the values of EC and $\mathrm{pH}$ decreased after cultivation, especially by using magnetized water., Concerning $\mathrm{Ca}^{2+}, \mathrm{Mg}^{2+}, \mathrm{Na}^{+}$and $\mathrm{K}^{+}$, the values indicated slight increase in $\mathrm{Ca}^{2+}, \mathrm{Mg}^{2+}$ and $\mathrm{K}^{+}$contents, while on the other hands, a slight decrease occurred in $\mathrm{Na}^{+}$contents of the investigated soils. These results indicate that the magnetization of water did not exert a significant effect on EC values after the harvest.

It is noticed from Table (4) that slight decreases occurred in both $\mathrm{HCO}_{3}^{-}$and $\mathrm{Cl}^{-}$ contents by using magnetized water. However, the concentration of $\mathrm{SO}_{4}{ }^{2-}$ increased in all the used soils.

Regarding to the effect of the organic matter, data indicated that the concentrations of $\mathrm{Ca}^{2+}$ increased while the concentration of $\mathrm{Na}^{+}$ decreased with O.M as compared without O.M. Additionally, the O.M has an important role in decreasing of the $\mathrm{pH}$ soil. These results are in harmony with those obtained by (Mohamed and Ebead, 2013) who found that the use of magnetically treated irrigation water reduced soil $\mathrm{pH}$ and increased some certain nutrients especially $\mathrm{P}$ and $\mathrm{K}$. Likewise, Maheshwari and Grewal, (2009) found that the magnetic treatment of irrigation water had no significant effect on EC values after the harvest of celery plants and significant decrease in soil $\mathrm{pH}$ and $\mathrm{Na}$ and increase in $\mathrm{Ca}$ and $\mathrm{P}$.

\subsection{Effect of magnetized water on the available contents of $N, P$ and $K$ of the investigated soils}

Data presented in Table (5) and Fig. (2) show the changes in the available contents of $\mathrm{N}$, $\mathrm{P}$ and $\mathrm{K}$ as affected by using the magnetized water in the investigated soils after harvest of the maize crop. Results indicated that the 
Table (3): Effect of magnetized waters on hydraulic conductivity of the investigated soils.

\begin{tabular}{|c|c|c|c|c|c|c|c|}
\hline Soil sample (S) & & $\begin{array}{r}\text { WateI } \\
\text { treatment }\end{array}$ & & \multicolumn{2}{|c|}{ Soil treatment $(\mathbf{T})$} & \multicolumn{2}{|c|}{$\mathrm{HC}\left(\mathrm{cm} \mathrm{h}^{-1}\right)$} \\
\hline \multirow{5}{*}{$\begin{array}{l}\text { The clay loam } \\
\text { (Mashtol El-Souq) }\end{array}$} & \multicolumn{5}{|c|}{ Before cultivation } & \multicolumn{2}{|c|}{1.23} \\
\hline & \multicolumn{3}{|c|}{ N.W } & \multicolumn{2}{|c|}{$\begin{array}{l}\text { without O.M. } \\
\text { with O.M. }\end{array}$} & \multicolumn{2}{|c|}{$-\ldots .23$} \\
\hline & \multicolumn{5}{|c|}{ Mean } & \multicolumn{2}{|c|}{1.38} \\
\hline & \multicolumn{3}{|c|}{ M.W } & \multicolumn{2}{|c|}{$\begin{array}{l}\text { without O.M. } \\
\text { with O.M. }\end{array}$} & \multicolumn{2}{|c|}{$\begin{array}{r}1.65 \\
-1.98 \\
\end{array}$} \\
\hline & \multicolumn{5}{|c|}{ Mean } & \multicolumn{2}{|c|}{1.82} \\
\hline \multirow{5}{*}{$\begin{array}{c}\text { The sandy } \\
\text { (Wade El-Natroon) }\end{array}$} & \multicolumn{5}{|c|}{ Before cultivation } & \multicolumn{2}{|c|}{62.22} \\
\hline & \multicolumn{3}{|c|}{ N.W } & \multicolumn{2}{|c|}{$\begin{array}{l}\text { without O.M. } \\
\text { with O.M. } \\
\end{array}$} & \multicolumn{2}{|c|}{$-62.23-$} \\
\hline & \multicolumn{5}{|c|}{ Mean } & \multicolumn{2}{|c|}{62.08} \\
\hline & \multicolumn{3}{|c|}{ M.W } & \multicolumn{2}{|c|}{$\begin{array}{l}\text { without O.M. } \\
\text { with O.M. }\end{array}$} & \multicolumn{2}{|c|}{$-64.46-.5-$} \\
\hline & \multicolumn{5}{|c|}{ Mean } & \multicolumn{2}{|c|}{64.03} \\
\hline \multirow{5}{*}{$\begin{array}{l}\text { The } \\
\text { Calcareous } \\
\text { (El-Nobaria) }\end{array}$} & \multicolumn{5}{|c|}{ Before cultivation } & \multicolumn{2}{|c|}{6.75} \\
\hline & \multicolumn{3}{|c|}{ N.W } & \multicolumn{2}{|c|}{$\begin{array}{l}\text { without O.M. } \\
\text { with O.M. } \\
\text { with }\end{array}$} & \multicolumn{2}{|c|}{$-\frac{6.61}{6.40}$} \\
\hline & \multicolumn{5}{|c|}{ Mean } & & \\
\hline & & M.W & & $\begin{array}{l}\text { without } \\
\text { with } \mathrm{O} . \mathrm{M}\end{array}$ & ---- & -- & \\
\hline & & & Me: & & & & \\
\hline Moon & & N.W & & $\begin{array}{l}\text { without } \\
\text { with } \bar{O}-\mathrm{M}\end{array}$ & $-\cdots$ & $---\frac{2}{2}$ & \\
\hline viean & & M.W & & $\begin{array}{l}\text { without } \\
\text { with } 0 . M\end{array}$ & $-\ldots$ & $---\frac{2}{2}$ & $-\cdots$ \\
\hline & & Mea & & & & & \\
\hline L.S. $D_{0.05}$ & $\mathrm{~S}$ & $\mathrm{~W}$ & $\mathrm{~T}$ & $\mathrm{SxW}$ & SxT & WxT & SxWxT \\
\hline $\mathrm{HC}$ & 0.039 & 0.032 & 0.032 & 0.055 & 0.055 & 0.045 & 0.078 \\
\hline
\end{tabular}

magnetized water resulted in significant increases in available contents $\mathrm{N}, \mathrm{P}$ and $\mathrm{K}$ as compared with non-magnetized in all the used soils. The highest mean values of $\mathrm{N}$ concentration were attained due to M.W and O.M in the clay soil.

The highest values for $\mathrm{N}, \mathrm{P}$ and $\mathrm{K}$ were 47.25 , 5.05 and $31.44 \mathrm{mg} \mathrm{kg}^{-1}$ respectively in the clay soil with magnetized water and organic matter while the lowest ones were found upon the M.W and O.M in the sandy soil. For the sandy soil, the percentages of increase of the available $\mathrm{N}, \mathrm{P}$ and $\mathrm{K}$ due to magnetized water over nonmagnetized water were $1.89,5.07$ and $3.5 \%$, respectively.

These results indicated that using of magnetized irrigation water resulted in significant increase in the available soil $\mathrm{N}, \mathrm{P}$ and $\mathrm{K}$ as compared with non- magnetized water. The magnetized water is able to dissolve the nutrients than the non- magnetized water, additionally the soil $\mathrm{pH}$ decreased with magnetized water, which leads to increasing availability of most nutrients for plant.

This finding is in agreement with those of Maheshwari and Grewal (2009) and Mohamed and Ebead (2013); who found that the use of magnetized water increased available soil $\mathrm{P}$ and $\mathrm{K}$ and organic nutrients while decreased soil $\mathrm{pH}$. Hassan (2015) reported that the magnetized water enhanced the release of nutrients in soil and adjusted its $\mathrm{pH}$ value, which will reflect positively on the plant and its yield. 

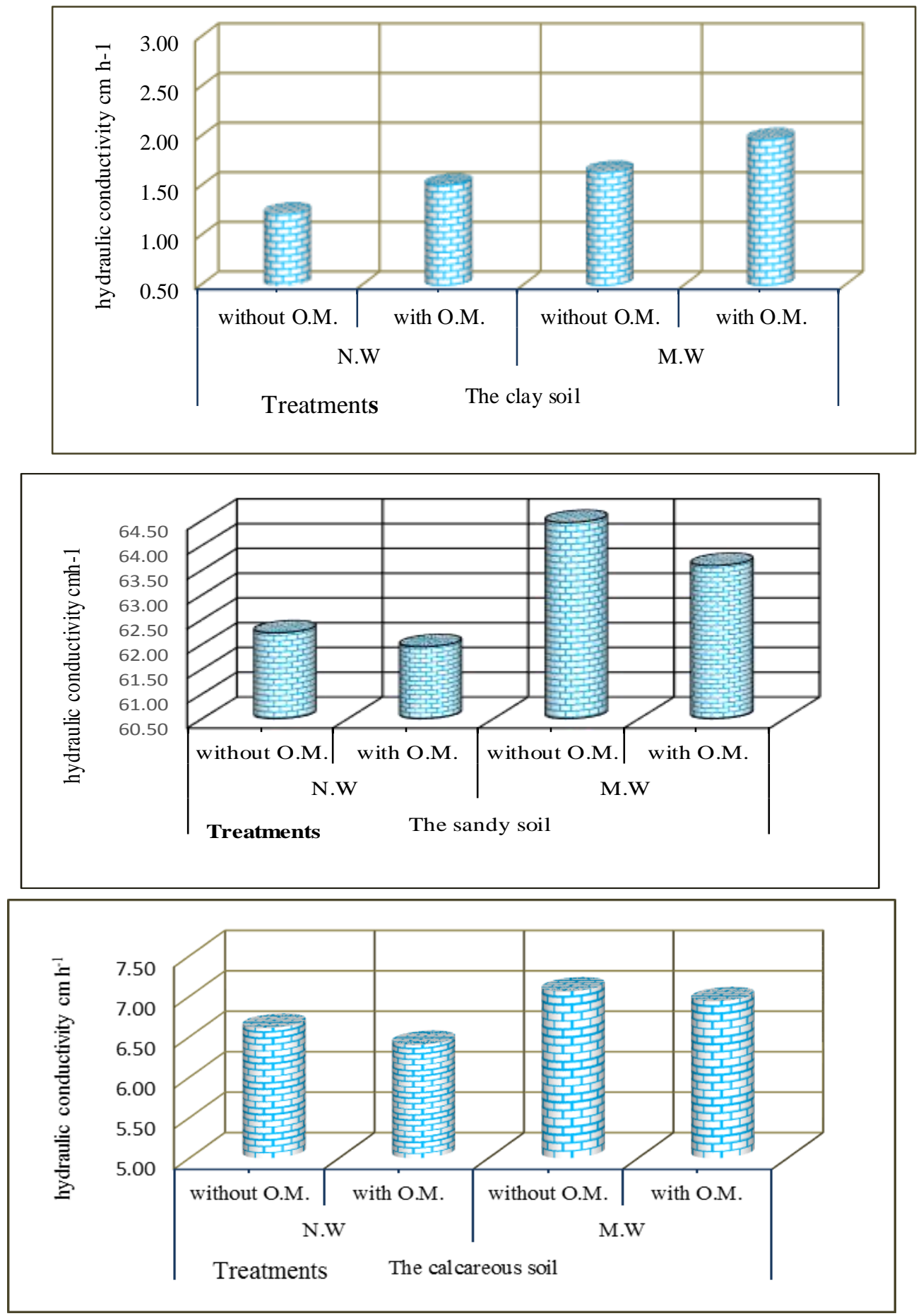

Fig. (1): Effect of magnetized water on hydraulic conductivity of the investigated soils.

Effect of magnetized water on soluble ions, organic matter and $\mathrm{CaCO}_{3}$ contents of the investigated soils after harvest of plants. 
Table (4) :Effect of magnetized water on soluble ions, organic matter and $\mathrm{CaCO}_{3}$ contents of the investigated soils after harvest of maize plants

\begin{tabular}{|c|c|c|c|c|c|c|c|c|c|c|c|c|c|c|}
\hline \multirow{2}{*}{$\begin{array}{c}\text { Soil } \\
\text { sample }\end{array}$} & \multirow{2}{*}{$\begin{array}{l}\text { Water } \\
\text { treatment }\end{array}$} & \multirow{2}{*}{$\begin{array}{c}\text { Soil } \\
\text { treatment }\end{array}$} & \multirow{2}{*}{$\begin{array}{c}\mathrm{EC} \mathrm{dSm}^{-1} \\
1: 5 \\
\text { Soil water } \\
\text { extract }\end{array}$} & \multirow{2}{*}{$\begin{array}{c}\text { pH } \\
\text { 1:2.5 } \\
\text { Soil } \\
\text { suspension }\end{array}$} & \multicolumn{8}{|c|}{$\begin{array}{c}\text { Soluble ions in } 1: 5 \text { soil water } \\
\text { extract }\left(\mathrm{Cmol} \mathrm{kg} \mathrm{kg}^{-1}\right)\end{array}$} & \multirow[b]{2}{*}{$\begin{array}{r}\text { O.M } \\
\mathrm{g} \mathrm{kg}^{-1}\end{array}$} & \multirow[b]{2}{*}{$\begin{array}{c}\mathrm{CaCO}_{3} \\
\mathrm{~g} \mathrm{~kg}^{-1}\end{array}$} \\
\hline & & & & & $\mathrm{Ca}^{2+}$ & $\mathbf{M g}^{2+}$ & $\mathbf{N a}^{+}$ & $\mathbf{K}^{+}$ & $\mathrm{CO}_{3}{ }^{2-}$ & $\mathrm{HCO}_{3}^{-}$ & $\mathrm{Cl}^{-}$ & $\mathrm{SO}_{4}{ }^{2-}$ & & \\
\hline \multirow{4}{*}{$\begin{array}{c}\text { The clay loam } \\
\text { (Mashtol El- } \\
\text { Souq) }\end{array}$} & \multirow{2}{*}{ N.W } & without O.M. & & 7.80 & 3.51 & 1.95 & 3.00 & 0.04 & - & -1.18 & 2.37 & 4.95 & 10.10 & 32.00 \\
\hline & & with O.M. & 1.81 & 7.74 & 3.62 & 2.20 & 2.85 & 0.09 & & 1.15 & 2.25 & 5.36 & 12.20 & 30.90 \\
\hline & \multirow{2}{*}{ M.W } & without O.M. & 1.80 & 7.73 & 3.58 & 2.05 & 2.89 & 0.08 & - & 1.16 & 2.31 & 5.13 & 10.20 & 31.20 \\
\hline & & with O.M. & 1.75 & 7.65 & 3.69 & 2.25 & 2.71 & 0.12 & & 1.08 & 2.21 & 5.48 & 12.60 & 29.70 \\
\hline \multirow{4}{*}{$\begin{array}{l}\text { The sandy } \\
\text { (Wade El- } \\
\text { Natroon) }\end{array}$} & \multirow{2}{*}{ N.W } & without O.M. & 2.14 & $\begin{array}{r}7.80 \\
-.-1\end{array}$ & 4.45 & 3.85 & 2.25 & 0.03 & - & 2.24 & 2.21 & 6.11 & 3.70 & 87.70 \\
\hline & & with O.M. & 2.11 & 7.80 & 4.51 & 3.95 & 2.18 & 0.04 & - & 2.21 & 2.18 & 6.29 & 7.60 & 87.50 \\
\hline & \multirow{2}{*}{ M.W } & without O.M. & 2.10 & 7.51 & $\begin{array}{l}4.47 \\
-. .-2\end{array}$ & 3.94 & 2.20 & 0.04 & - & 2.22 & 2.20 & 6.23 & 3.40 & 87.30 \\
\hline & & with O.M. & 2.09 & 7.46 & 4.54 & 4.00 & 2.12 & 0.08 & & 2.19 & 2.15 & 6.40 & 8.00 & 87.10 \\
\hline \multirow{4}{*}{$\begin{array}{c}\text { The } \\
\text { Calcareous } \\
\text { (El-Nobaria) }\end{array}$} & \multirow{2}{*}{ N.W } & without O.M. & 2.91 & 8.01 & $\begin{array}{r}6.93 \\
-. .\end{array}$ & 5.18 & 2.53 & 0.15 & - & 3.87 & 2.34 & 8.58 & 7.50 & 186.00 \\
\hline & & & 2.87 & 7.85 & 7.05 & 5.23 & 2.35 & 0.18 & & 3.80 & 2.30 & 8.71 & 8.50 & 185.20 \\
\hline & \multirow{2}{*}{ M.W } & without O.M. & 2.89 & 7.83 & 6.99 & 5.22 & 2.40 & 0.17 & - & 3.82 & 2.31 & 8.65 & 7.90 & 185.70 \\
\hline & & with O.M. & 2.85 & 7.78 & 7.10 & 5.25 & 2.25 & 0.21 & & 3.78 & 2.25 & 8.78 & 8.60 & 184.50 \\
\hline
\end{tabular}

N.W: non-magnetized water 
Table (5): Effect of magnetized water on the available contents of $\mathrm{N}, \mathrm{P}$ and $\mathrm{K}\left(\mathrm{mg} \mathrm{kg}^{-1}\right)$ of the investigated soils after harvest maize crop

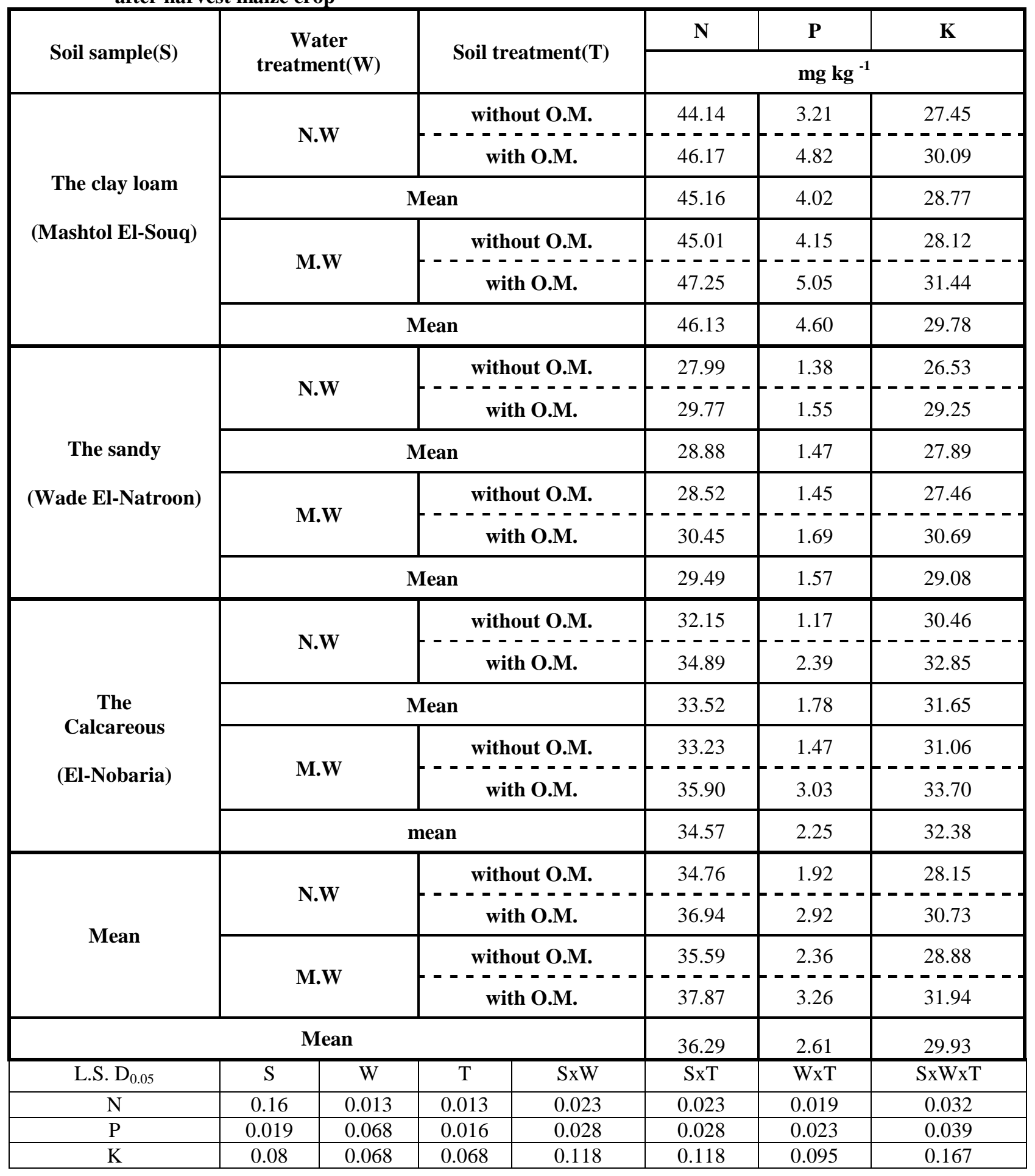

Mohamed and Ebead (2013) found that the mobility field to irrigation water was shown to increase plant nutrient content Moon and Chung (2000). Noran et al. (1996) found that magnetic treatment of water may be influencing desorption of $\mathrm{P}$ and $\mathrm{K}$ from soil colloidal of nutrient elements in root zone of citrus differed greatly from element to another according to element magnetic susceptibility. Application of a magnetic treatment of water may be influencing desorption of $\mathrm{P}$ and $\mathrm{K}$ from soil colloidal complex, and thus increasing their availability to plants, and thus resulting in an improved plant growth and productivity. 


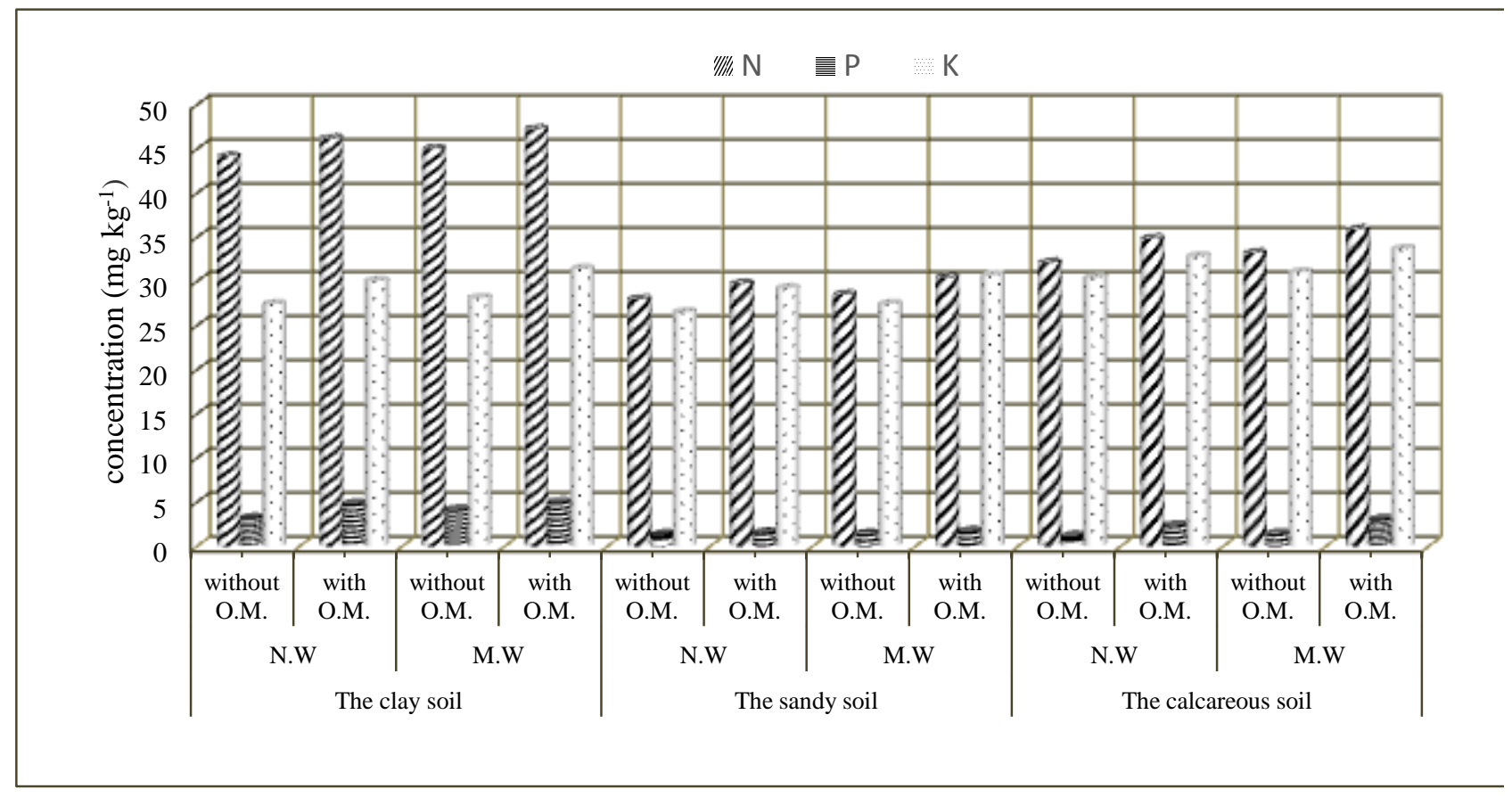

Fig. (2): Effect of magnetized water on the available contents of $N, P$ and $K\left(\mathrm{mg} \mathrm{kg}^{-1}\right)$ of the investigated soils after harvest maize crop.

treatment of water may be influencing desorption of $\mathrm{P}$ and $\mathrm{K}$ from soil colloidal complex, and thus increasing their availability to plants, and thus resulting in an improved plant growth and productivity.

\subsection{Effect of magnetized water on the \\ germination of maize plant}

Data in Table (6) show the effect of magnetized water on germination of maize grains in the clay, sandy and calcareous soils as compared with non -magnetized water. Results indicate that the (M.W) and organic matter resulted in the high seed germination.

The percentages of increase were 10.10, 5.89 and $21 \%$ for magnetized water compared with non-magnetized water in the clay, sandy and calcareous soils respectively after 6 days, also addition of the organic matter could also increase seed germination.

These results are in agreement with those of Selim (2008) who found that application of magnetized water increased percentage of seed germination. The magnetic field affected the water relations to seeds germination such as: the ionic concentration, osmotic pressure and water uptake rate.

The positive effect of the used magnetized treatment on maize germination was reported by
Florez et al.,(2007) who found increase in the percentage of germination by 10, 25, 50, 75 and $90 \%$ when the seeds were magnetically exposed to one of two magnetic field strengths, 125 or $250 \mathrm{mT}$ for different periods of time. Ijaz et al. (2012) found that a $13.3 \%$ increase in germination was observed by using magnetized water as compared with non- magnetized.

\subsection{Effect of magnetic treatment on plant growth parameters:}

Data presented in Table (7) and Fig.(3) revealed increase in all tested growth parameters (plant height, fresh and dry weight of stem and root) of the maize with magnetized water.

The highest values of maize growth parameter (plant length $72 \mathrm{~cm}$, fresh shoot $52 \mathrm{~g}$, dry shoot $6.92 \mathrm{~g}$, fresh root $12.78 \mathrm{~g}$ and dry root $4.6 \mathrm{~g}$ ) were obtained by using magnetized water and organic matter addition in clay soil while the lowest values (plant length $40 \mathrm{~cm}$, fresh shoot $14.33 \mathrm{~g}$, dry shoot $3.83 \mathrm{~g}$, fresh root $5.49 \mathrm{~g}$, and dry root 3.21 g.) were obtained by using nonmagnetized irrigation water and without organic matter application in a sandy soil. Similar enhancing effect of magnetized irrigation water was reported by Mohamed (2013) and El Sayed (2014) who found that magnetized water improved fresh and dry weights of tomato plant. 
Table(6): Effect of magnetized water on the percentage of germination of maize plants

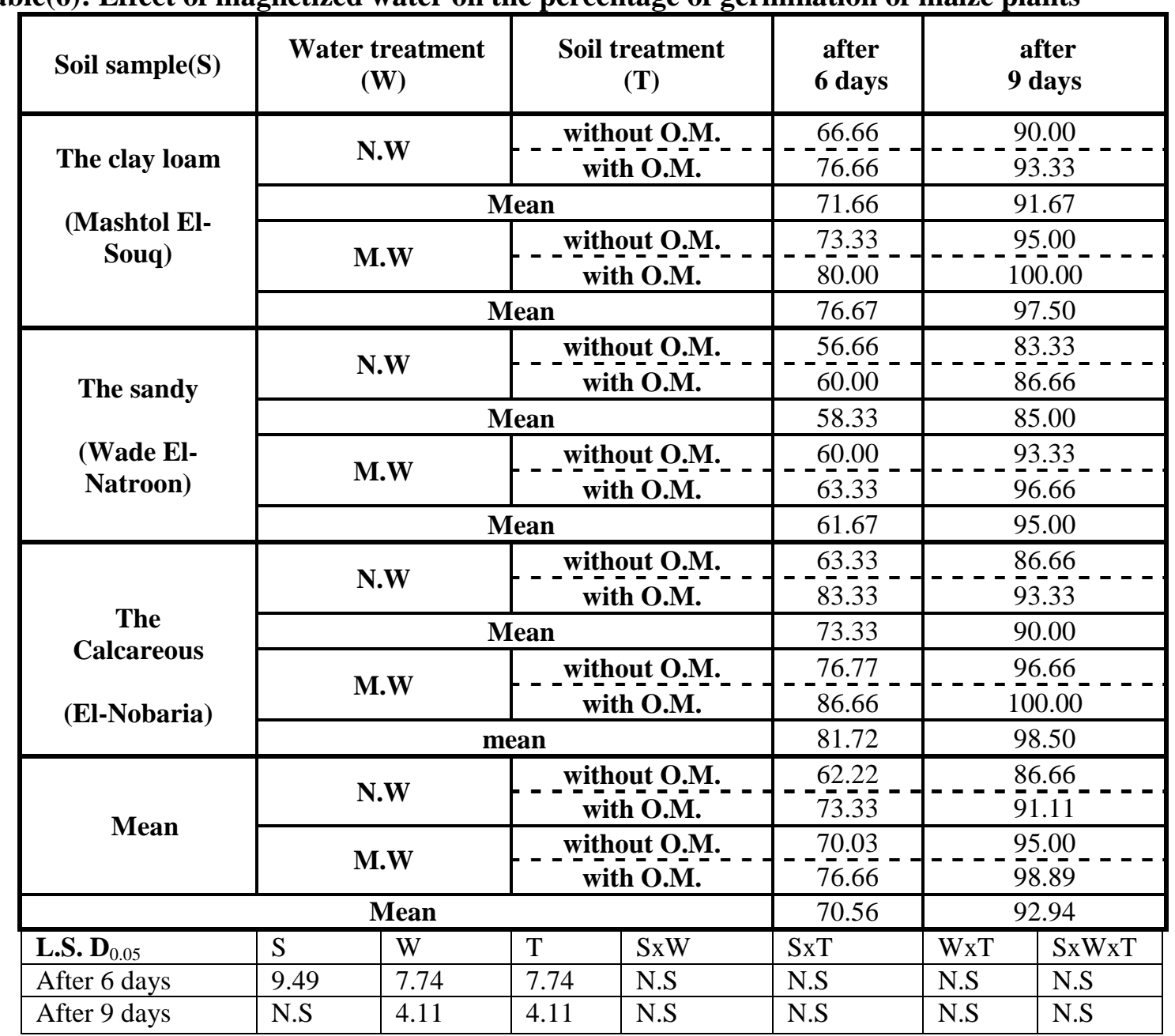

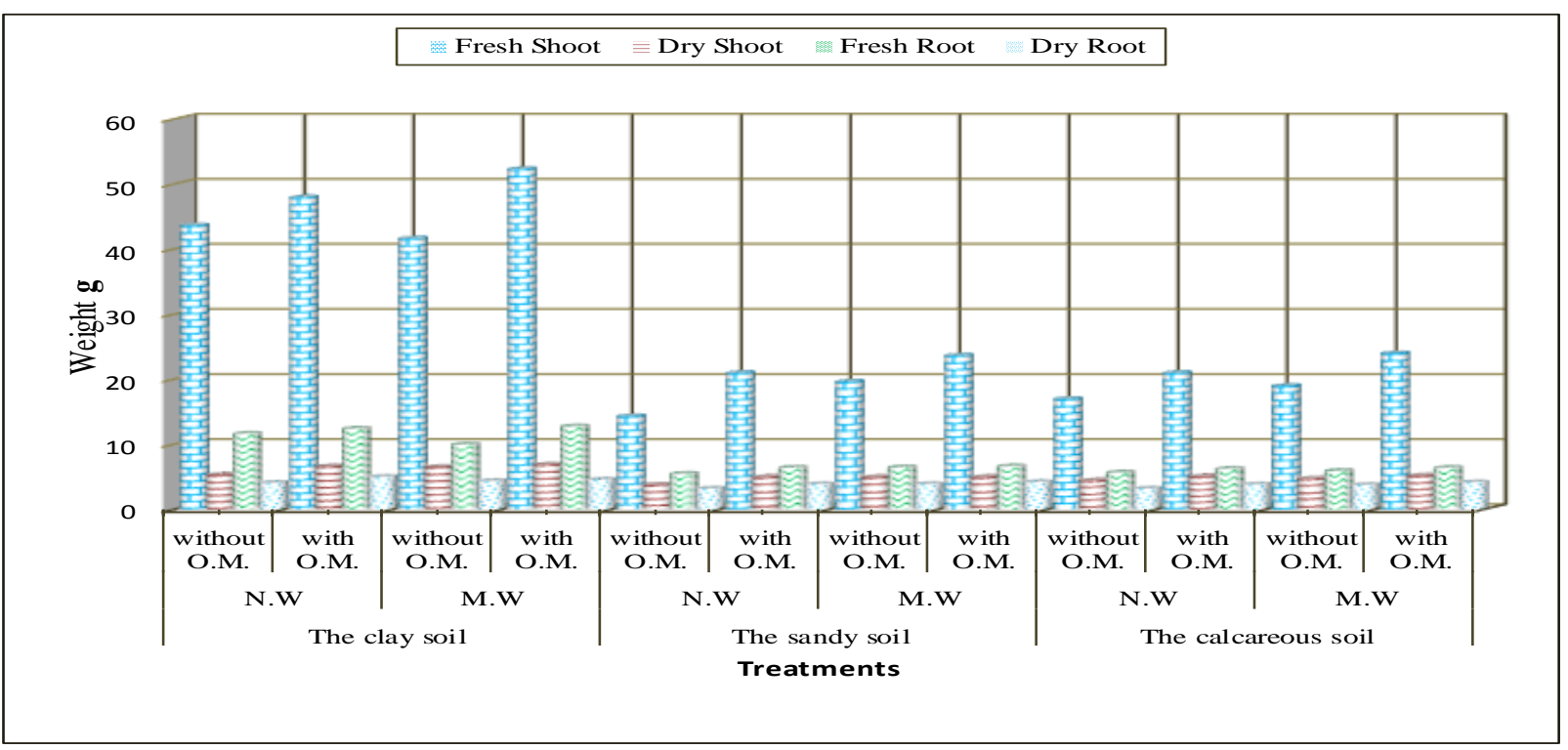

Fig. (3): Effect of magnetized water on maize plant growth parameters of maize plant

Effect of magnetized water on the uptake values of $N, P$ and $K$ of maize plant. 
Table (7): Effect of magnetic treatment on maize plant growth parameters.

\begin{tabular}{|c|c|c|c|c|c|c|c|}
\hline \multirow{2}{*}{$\begin{array}{c}\text { Soil } \\
\text { sample(S) }\end{array}$} & \multirow{2}{*}{$\begin{array}{l}\text { Water } \\
\text { treatment } \\
\text { (W) }\end{array}$} & \multirow{2}{*}{$\begin{array}{l}\text { Soil treatment } \\
\text { (T) }\end{array}$} & \multirow{2}{*}{$\begin{array}{c}\text { Plant } \\
\text { height } \\
\text { (cm) }\end{array}$} & \multicolumn{4}{|c|}{ Plant weight (g) } \\
\hline & & & & $\begin{array}{l}\text { Fresh } \\
\text { Shoot }\end{array}$ & $\begin{array}{c}\text { Dry } \\
\text { Shoot }\end{array}$ & $\begin{array}{c}\text { Fresh } \\
\text { Root }\end{array}$ & $\begin{array}{c}\text { Dry } \\
\text { Root }\end{array}$ \\
\hline \multirow{6}{*}{$\begin{array}{l}\text { The clay loam } \\
\text { (Mashtol El-Souq) }\end{array}$} & \multirow{2}{*}{ N.W } & \multirow{3}{*}{$\begin{array}{l}\text { Without O.M } \\
\text { with O.M. } \\
\text { Mean }\end{array}$} & 62.00 & 44 & 5.36 & 11.67 & 4.11 \\
\hline & & & 76.33 & 48 & 6.63 & 12.44 & 5.02 \\
\hline & Mean & & 69.17 & 45.83 & 6.00 & 12.05 & 4.57 \\
\hline & \multirow{2}{*}{ M.W } & Without O.M & 65.00 & 42 & 6.56 & 10.00 & 4.39 \\
\hline & & with O.M. & $\overline{72.00}$ & $\overline{52}$ & 6.92 & $12 . \overline{7} 8^{-}$ & 4.60 \\
\hline & \multicolumn{2}{|r|}{ Mean } & 68.50 & 47.00 & 6.74 & 11.39 & 4.49 \\
\hline \multirow{6}{*}{$\begin{array}{l}\text { The sandy } \\
\text { (Wade El- } \\
\text { Natroon) }\end{array}$} & \multirow{2}{*}{ N.W } & \multirow{2}{*}{\begin{tabular}{|c} 
Without O.M \\
with O.M.
\end{tabular}} & 40.00 & 14.33 & 3.83 & 5.49 & 3.21 \\
\hline & & & 44.33 & 21 & 5.01 & 6.44 & 3.91 \\
\hline & \multicolumn{2}{|r|}{ Mean } & 42.17 & 17.67 & 4.42 & 5.97 & 3.56 \\
\hline & \multirow{2}{*}{ M.W } & Without O.M & 42.66 & 20 & $\underline{4.99}$ & 6.50 & 3.92 \\
\hline & & with O.M. & 49.33 & 23.67 & 5.00 & 6.66 & 4.24 \\
\hline & \multicolumn{2}{|r|}{ Mean } & 46.00 & 21.67 & 5.00 & 6.58 & 4.08 \\
\hline \multirow{6}{*}{$\begin{array}{c}\text { The } \\
\text { Calcareous } \\
\text { (El-Nobaria) }\end{array}$} & \multirow{2}{*}{ N.W } & \multirow{2}{*}{$\begin{array}{l}\text { Without O.M } \\
\text { with O.M. }\end{array}$} & 39.33 & $-17 \ldots$ & 4.46 & 5.71 & 3.21 \\
\hline & & & 44.00 & 21 & 5.11 & 6.27 & 3.87 \\
\hline & \multicolumn{2}{|r|}{ Mean } & 41.67 & 19.00 & 4.79 & 5.99 & 3.54 \\
\hline & \multirow{2}{*}{ M.W } & \multirow{2}{*}{ Without O.M } & 41.00 & 19 & 4.78 & 5.95 & 3.78 \\
\hline & & & 49.33 & 24 & 5.22 & 6.41 & 4.20 \\
\hline & \multicolumn{2}{|r|}{ Mean } & 45.17 & 21.50 & 5.00 & 6.18 & 3.99 \\
\hline \multirow{3}{*}{ Mean } & N.W & Without O.M & 47.11 & $-\frac{25}{30}-$. & $\frac{4.55}{5}$ & 7.62 & 3.51 \\
\hline & & Without O.M & $\frac{54.89}{47.83}$ & $\begin{array}{l}30 \\
27\end{array}$ & $\frac{5.58}{5.44}$ & $\frac{8.38}{7.48}$ & $\frac{4.26}{4.03}$ \\
\hline & M.W & & 56.89 & $-\frac{1}{3}$ & $5 . \overline{7}$ & 8.62 & 4.34 \\
\hline \multicolumn{3}{|c|}{ Mean } & 52.11 & 28.78 & 5.32 & 8.03 & 4.04 \\
\hline L.S.D 0.05 & $\mathrm{~S}$ & $\mathrm{~W}$ & $\mathrm{~T}$ & $\mathrm{SxW}$ & $\mathrm{S} \times \mathrm{T}$ & $\mathrm{WxT}$ & SxWxT \\
\hline Plant length & 1.65 & 1.35 & 1.35 & N.S & N.S & N.S & N.S \\
\hline Fresh Shoot & 2.41 & 1.97 & 1.97 & N.S & N.S & N.S & N.S \\
\hline Dry Shoot & 0.23 & 0.19 & 0.19 & N.S & N.S & 0.27 & N.S \\
\hline Fresh Root & 0.43 & N.S & 0.35 & 0.61 & 0.61 & N.S & 0.86 \\
\hline Dry Root & 0.25 & 0.20 & 0.20 & 0.35 & N.S & 0.28 & N.S \\
\hline
\end{tabular}

It appears that utilization of magnetized water technology may be considered a promising technique to improve tomato yield productivity. The use of magnetic techniques with low quality water is very important for irrigation without any expected problems in the soils and the plants.

The data of $\mathrm{N}, \mathrm{P}$ and $\mathrm{K}$ uptake by maize plants are shown in Table (8) and in Fig. (4) results indicated that the uptake of $\mathrm{N}, \mathrm{P}$ and $\mathrm{K}$ as well of maize plants were significantly increased with magnetized water. The highest mean values were $147.57,34.59$ and $118.51 \mathrm{mg}^{-t^{-1}}$ for $\mathrm{N}, \mathrm{P}$ and $\mathrm{K}$, respectively, in the clay soil, while the lowest mean values were 78.27, 17.67 and 97.28 mg pot ${ }^{-1}$ in the sandy soil.

The percentages of increase of $\mathrm{N}$ uptake for the magnetized water compared with nonmagnetized water were 27,38 and $11.61 \%$ for the clay, sandy and calcareous soils, respectively, the percentage of increase of $\mathrm{P}$ uptake were $51.21,71.55$ and $25.62 \%$ while the percentage of increase of K uptake were 27.51, 38.40 and $10 \%$ for the clay, sandy and calcareous soils, respectively. It is noticed from the data that the magnetized water more positive effect in sandy soils. Data also indicated that the $\mathrm{N}, \mathrm{P}$ and $\mathrm{K}$ uptake of maize plants increased when the soil was treated with organic matter. These results in agreement with those obtained by El sayed (2014) who found that increase in $\mathrm{Ca}, \mathrm{P}$ and $\mathrm{K}$ contents in broad bean plants by magnetized water.

It appears that utilization of magnetized water technology may be considered a promising technique to improve tomato yield productivity. The use of magnetic techniques with low quality water is very important for irrigation without any expected problems in the soils and the plants. 
Table (8): Effect of magnetized water on uptake values of N, P and K (mg pot ${ }^{-1}$ ) by maize plant.

\begin{tabular}{|c|c|c|c|c|c|c|c|}
\hline \multirow{2}{*}{\multicolumn{2}{|c|}{$\begin{array}{l}\text { Soil sample } \\
\text { (S) }\end{array}$}} & \multirow{2}{*}{$\begin{array}{c}\text { Water } \\
\text { treatment } \\
(W)\end{array}$} & \multirow{2}{*}{\multicolumn{2}{|c|}{$\begin{array}{c}\text { Soil treatment } \\
\text { (T) }\end{array}$}} & $\mathbf{N}$ & $\mathbf{P}$ & $\mathbf{K}$ \\
\hline & & & & & \multicolumn{3}{|c|}{ mg pot $^{-1}$} \\
\hline \multirow{4}{*}{\multicolumn{2}{|c|}{$\begin{array}{c}\text { The clay loam } \\
\text { (Mashtol El-Souq) }\end{array}$}} & N.W & \multicolumn{2}{|c|}{$\begin{array}{c}\text { without O.M. } \\
\text { with O.M. }\end{array}$} & $-\frac{96.67}{129.09}$ & $--\frac{13.63}{26.30}=$ & $\begin{array}{c}85.87 \\
----- \\
116.45\end{array}$ \\
\hline & & \multicolumn{3}{|c|}{ Mean } & 112.88 & 19.97 & 101.16 \\
\hline & & M.W & \multicolumn{2}{|c|}{$\begin{array}{c}\text { without O.M. } \\
\text { with O.M. }\end{array}$} & $-\frac{123.28}{147.57}$ & $--\frac{20.61}{34.59}-$ & $\begin{array}{c}109.50 \\
118.51\end{array}$ \\
\hline & & \multicolumn{3}{|c|}{ Mean } & 135.43 & 27.60 & 114.01 \\
\hline \multirow{4}{*}{\multicolumn{2}{|c|}{$\begin{array}{c}\text { The sandy } \\
\text { (Wade El-Natroon) }\end{array}$}} & N.W & \multicolumn{2}{|c|}{$\begin{array}{c}\text { without O.M. } \\
\text { with O.M. }\end{array}$} & $-\frac{51.85}{73.51}$ & $--\frac{7.77}{14.72}=$ & $\begin{array}{c}66.90 \\
----- \\
95.07 \\
\end{array}$ \\
\hline & & \multicolumn{3}{|c|}{ Mean } & 62.68 & 11.25 & 80.98 \\
\hline & & M.W & \multicolumn{2}{|c|}{$\begin{array}{c}\text { without O.M. } \\
\text { with O.M. }\end{array}$} & $-\frac{71.92}{78.27}$ & $--\frac{13.33}{17.67}=$ & $\frac{92.42}{--2}-$ \\
\hline & & \multicolumn{3}{|c|}{ Mean } & 75.09 & 15.5 & 94.85 \\
\hline \multirow{4}{*}{\multicolumn{2}{|c|}{$\begin{array}{c}\text { The } \\
\text { Calcareous } \\
\text { (El-Nobaria) }\end{array}$}} & N.W & \multicolumn{2}{|c|}{$\begin{array}{c}\text { without O.M. } \\
\text { with O.M. }\end{array}$} & $-\frac{69.33}{84.28}$ & $--\frac{8.78}{13.46}=$ & $\begin{array}{c}80.49 \\
----- \\
97.89\end{array}$ \\
\hline & & \multicolumn{3}{|c|}{ Mean } & 76.81 & 11.12 & 89.19 \\
\hline & & M.W & \multicolumn{2}{|c|}{$\begin{array}{c}\text { without O.M. } \\
\text { with O.M. }\end{array}$} & $\begin{array}{r}-77.38 \\
-\mathbf{-} \\
95.07\end{array}$ & $-\frac{11.03}{17.76}=$ & $\begin{array}{c}-\frac{88.51}{-1}- \\
101.89\end{array}$ \\
\hline & & \multicolumn{3}{|c|}{ mean } & 86.22 & 14.40 & 95.20 \\
\hline \multirow{2}{*}{\multicolumn{2}{|c|}{ Mean }} & N.W & \multicolumn{2}{|c|}{$\begin{array}{c}\text { without O.M. } \\
\text { with O.M. }\end{array}$} & $\begin{array}{r}72.62 \\
95.63 \\
\end{array}$ & $\begin{array}{c}-\frac{10.06}{18.16}- \\
\end{array}$ & $\frac{77.75}{103.14}$ \\
\hline & & M.W & \multicolumn{2}{|c|}{$\begin{array}{c}\text { without O.M. } \\
\text { with O.M. }\end{array}$} & $-\frac{90.86}{106.97}$ & $\begin{array}{c}-\frac{14.99}{23.34} \\
\end{array}$ & $\begin{array}{c}-\underline{96.81}-\underline{-}- \\
105.89\end{array}$ \\
\hline \multicolumn{5}{|c|}{ Mean } & 91.52 & 16.64 & 95.90 \\
\hline L.S. $\mathbf{D}_{0.05}$ & $\mathrm{~S}$ & $\mathrm{~W}$ & $\mathrm{~T}$ & SxW & SxT & WxT & SxWxT \\
\hline $\mathrm{N}$ & 4.42 & 3.61 & 3.61 & 6.25 & 6.25 & N.S & N.S \\
\hline $\mathrm{P}$ & 1.36 & 1.11 & 1.93 & 1.11 & 1.93 & N.S & N.S \\
\hline $\mathrm{K}$ & 5.40 & 4.41 & 4.41 & N.S & N.S & 6.24 & N.s \\
\hline
\end{tabular}

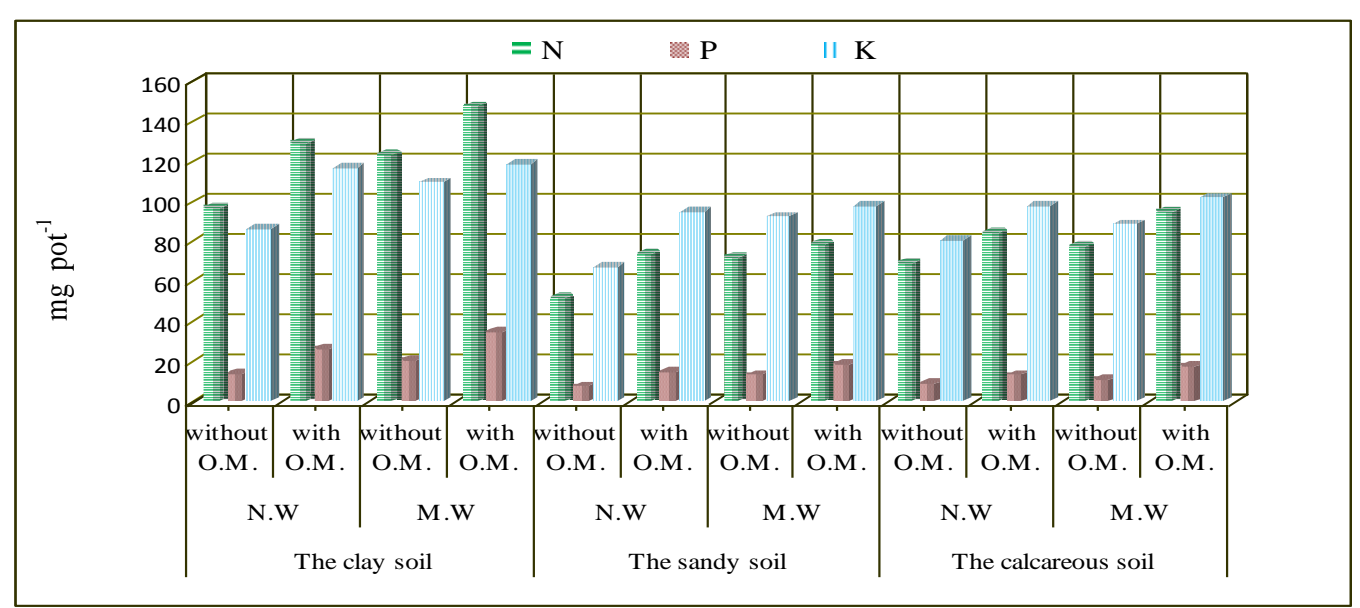

Fig. (4): Effect of magnetized water on uptake values of $N$, P and $K$ ( mg pot $^{-1}$ ) by maize plants. 
The data of $\mathrm{N}, \mathrm{P}$ and $\mathrm{K}$ uptake by maize plants are shown in Table (8) and in Fig. (4) results indicated that the uptake of $\mathrm{N}, \mathrm{P}$ and $\mathrm{K}$ as well of maize plants were significantly increased with magnetized water. The highest mean values were $147.57,34.59$ and $118.51 \mathrm{mg} \mathrm{pot}^{-1}$ for N, P and $\mathrm{K}$, respectively, in the clay soil, while the lowest mean values were 78.27, 17.67 and 97.28 mg $\operatorname{pot}^{-1}$ in the sandy soil.

The percentages of increase of $\mathrm{N}$ uptake for the magnetized water compared with nonmagnetized water were 27,38 and $11.61 \%$ for the clay, sandy and calcareous soils, respectively, the percentage of increase of $\mathrm{P}$ uptake were $51.21,71.55$ and $25.62 \%$ while the percentage of increase of $\mathrm{K}$ uptake were 27.51, 38.40 and $10 \%$ for the clay, sandy and calcareous soils, respectively. It is noticed from the data that the magnetized water more positive effect in sandy soils. Data also indicated that the $\mathrm{N}, \mathrm{P}$ and $\mathrm{K}$ uptake of maize plants increased when the soil was treated with organic matter. These results in agreement with those obtained by El sayed (2014) who found that increase in $\mathrm{Ca}, \mathrm{P}$ and $\mathrm{K}$ contents in broad bean plants by magnetized water.

\section{Conclution}

The aim of the current study was to evaluate the applicability of using the magnetized water and its effect on soil and plant properties. This study found that the effects of magnetic treatment on the used water were statistically significant increases in germination and plant growth parameter. On the other hand, as to soil properties after plant harvest, the use of magnetized water reduced soil $\mathrm{pH}$ and soil EC and increase in available N, P and $\mathrm{K}$. In general, the study indicates some useful and applied effects of magnetized water and its effect on some soil properties and plant growth and thus increase production.

\section{REFERENCES}

Active Standard ASTM D888, (2012). Standard test methods for dissolved oxygen in water.www. astem.org.

Aghamir F., Bahrami H., and Jafar M. (2016). Seed germination and seedling growth of bean (Phaseolus vulgaris) as influenced by magnetized saline water Eurasian. J. Soil Sci., 5(1): 1-8.

Ahmed M. E. M. and Abd El-kader N. I. A. (2016). The influence of magnetic water and water regimes on soil salinity, growth, yield and tubers quality of potato plants Middle East J. Agric. Res.,5 (2): 132-143.

Ali Y., Samaneh R., Zohre R. and Mostafa J. (2014). Magnetic Water Treatment in Environmental Management - A Review of the Recent Advances and Future Perspectives. Current World Environment, 9(3): 1008-1016.

Amiri M. C. and Dadkhah A. A. (2006). On reduction in the surface $t$ ension of water due to magnetic treatment Colloids and surfaces A: Physicochemical Engineering Aspects, 278: 252-255.

Bashour I.I. and Sayegh A. H. (2007). Methods of analysis for soils of arid and semi- arid regions. Food and Agriculture Organization of the United Nations.

Bogatin J., Bondarenko N. P., Gak E. Z., Rokhinson E. E. and Ananyev I. P. (1999). Magnetic treatment of irrigation water:Experimental results and application conditions. Environmental, Science and Technology, 33(8): 1280-1285.

Cottiene A., Nerloo M., Velghe G. and Kiekens (1982). Biological and Analytical Aspects of Soil Pollution Lab of analytical Agro. State. Univ. Ghent-belgium.

El Sayed H. A. (2014). Impact of Magnetic Water Irrigation for Improve the Growth, Chemical Composition and Yield Production of Broad Bean (Vicia faba L.). Plant, 4(4): 476-496.

Estefan G., Sommer R. and Ryan J. (2013). Methods of Soil, Plant, and Water Analysis: A manual for the West Asia and North Africa region, 143.

Florez M., Carbonell M.V., and Martinez E. (2007). Exposure of maize seeds to stationary magnetic fields: Effects on germination and early growth. Environ. Exp. Bot., 59:68-75.

Gomez K. A and Gomez A. A. (1984). Statistical Procedures for Agricultural Research $2^{\text {nd }}$ ed. Wily, New York, USA.

Hassan K. K. (2015). Magnetic Treatment of Brackish Water for Sustainable Agriculture, M. Sc. Thesis, School of Sciences and Engineering, the American University in Cairo.

Higashitani K. and Oshitani J. (1997). Measurements of Magnetic Effects on Electrolyte Solutions By Atomic Force Microscope.Institiwtion of Chemical Engineers, 75:115-119. 
Hilal M.H. and Hillal, M. M. (2000a). Application of magnetic technologies in desert agriculture .1-Seed germination and seedling emergence of some crop in a saline calcareous soil. Egypt J. Soil Sci. 40:(3):413-421.

Ijaz B., Ahmad S., Ahmad D., Shahid, M. and Uddin S. (2012). Changes in germination behavior of wheat seeds exposed to magnetic field and magnetically structured water. African J. Biotech., II(15): 35753582.

Khoshravesh M., Mostafazadeh-Fard B., Mousavi S. F. and Kiani A. R. (2011). Effects of magnetized water on the distribution pattern of soil water with respect to time in trickle irrigation. Soil Use and Management, 27(4): 515-522.

Klute, A. (1986). Water retention Laboratory methods p.635- 626.In: A. Klute (ed) Method of soil analysis. Part. $1.2^{\text {nd }}$ ed., Agron. Monogr., 9. ASA and SSSA, Madison, WI, USA.

Leoppert R.H and Suarez D.L. (1996). Carbonate and gypsum in: methods of soil analysis part-3 chemical methods. Sparks, D. L, (ed.), 434-474. Soil Science Society of America, Book series 5, Madison, WI.

Levitt B.P. (1972). Practical physical chemistry. $9^{\text {th }}$ ed. William sons; London, UK.

Maheshwari B. L. and Grewal H. S. (2009). Magnetic treatment of irrigation water: its effects on vegetable crop yield and water productivity. Agric. Water Manag., 96: 1229-1236.

Mohamed A. I. (2013). Effect of irrigation with magnetically treated water on faba bean growth and composition. International Journal of Agricultural Policy and Research, 1(April): 24- 40.

Mohamed A. I. and Ebead B. M. (2013). Effect of magnetic treated irrigation water on salt removal from a sandy soil and on the availability of certain nutrients. International Journal of Engineering and Applied Sciences, 2(2):36-44.

Moon J.D. and Chung H. S. (2000). Acceleration of germination of tomato seed by applying an electric and magnetic field. J. Electro-Stati., 48:103-114.

Mostafazadeh-fard B., Khoshravesh M. and Mousavi S. (2011). Effects of Magnetized
Water on Soil Sulphate Ions in Trickle Irrigation $2^{\text {nd }}$ International Conference on Environmental Engineering and Aplications, 17: 94-99.

Noran R., Shani U. R. I. and Lin I. (1996). The effect of irrigation with magnetically treated water on the translocation of minerals in the soil. Magnetic and Electrical Separation, 7(C), 109-122.

Page A.L., Miller R. H. and Keeney D. R. (1982). Methods of Soil Analysis Part 2: Chemical and Microbiological Analysis. Am. Soc., Madison, Wisconsin, USA.

Pang X.-F. and Deng B. (2008a). The changes of macroscopic features and microscopic structures of water under influence of magnetic field. Physica B-Condensed Matter, 403(19-20): 3571-3577.

Pang X. F. and Deng B. (2008b). Investigation of changes in properties of water under the action of a magnetic field, Sci. China Ser. G: Phys. Mech. Astron.51:1621-1632.

Pansu M. (2003). Hand book of soil analysis mineralogical, organic and inorganic methods, Springer-Verlag, Berlin Heidelberg New York, USA.

Sarkar D. and Haldar A. (2005). Physical and chemical methods in soil analysis, New Age International, New Delhi, India.

Selim M. M. (2008). Application of Magnetic Technologies in correcting underground brackish water for irrigation in the Arid and Semi-Arid Ecosystem. The 3 ${ }^{r d}$ International Conference on Water Resources and Arid Environment, Cairo, Egypt.

Takatshinko Y. (1997) .Hydromagnetic systems and their role in creating microclimate. International Symposium on Sustainable Management of Salt Affected Soils, Cairo, Egypt, 22-28 Sept.

USADA (1996). Soil survey laboratory methods manual, soil Survey investigations, Natural Resources Conservation Service, US Department of Agriculture, Report No. 42, V.3, Washington, DC, USA.

Yang G., Wang, J., Mei Y. and Luan Z.(2011). Effect of magnetic field on protein and oxygen-production of chlorella vulgaris. Mathematical and Physical Fisheries Science, 9: 116-126. 


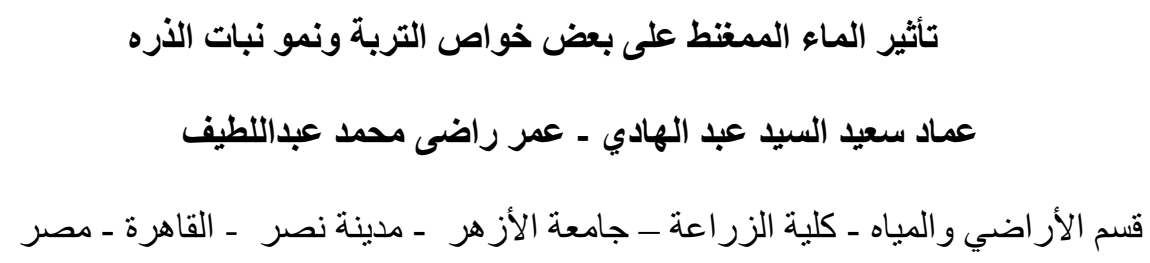

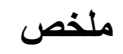

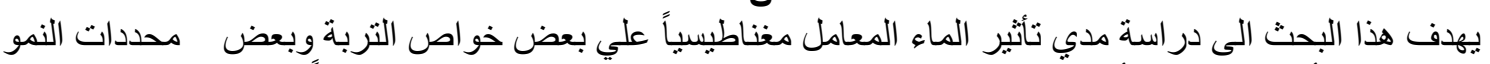

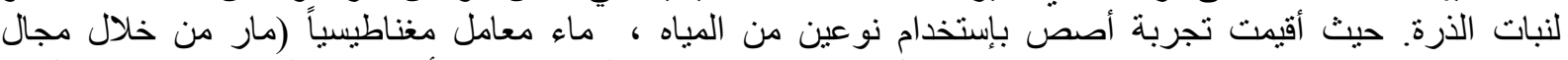

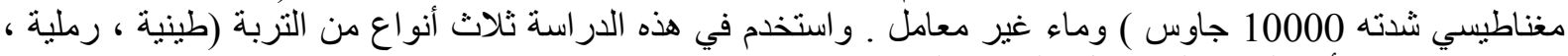

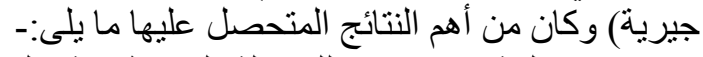

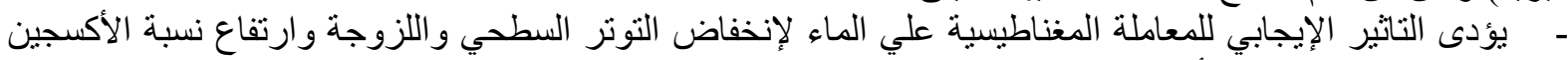

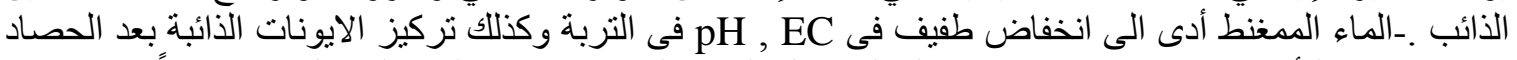

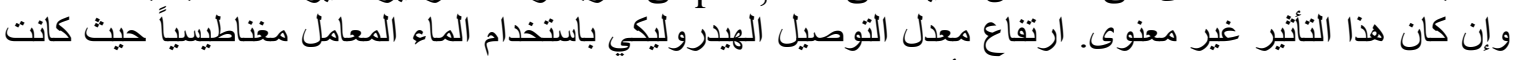

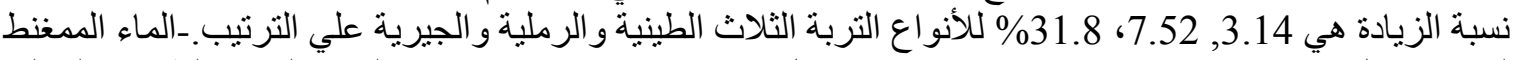

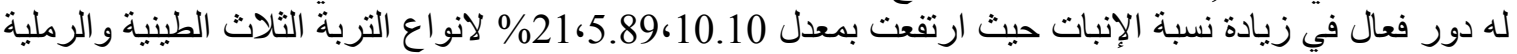

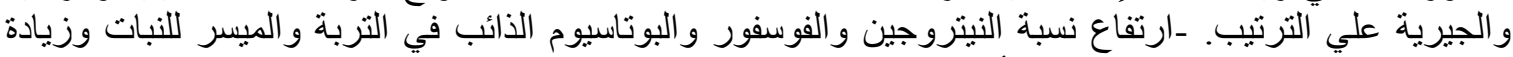

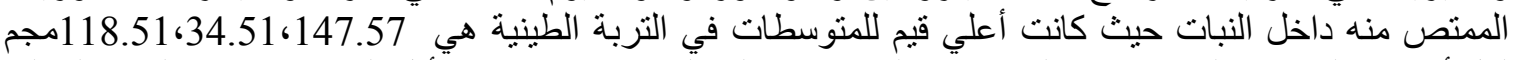

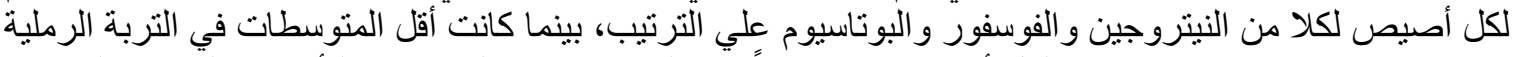

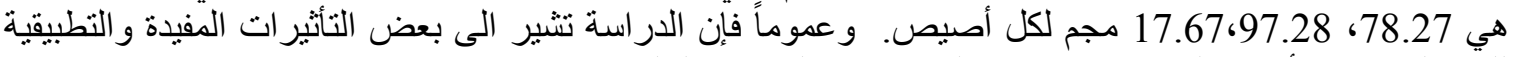

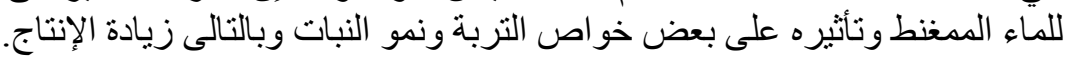

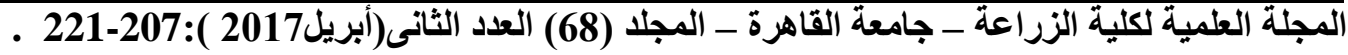

